Volume: 11

Issue: 04

Years: 2021

\section{Original Articles \\ Relationship between Anxiety Levels and Smoking Behavior in Early Adolescents in Nias Ciranjang Junior High School}

\author{
Radina Ratnasari ${ }^{1}$, Dewi Umu Kulsum², \\ Dwi Hastuti ${ }^{3}$ \\ ${ }^{1-3}$ STIKes Jenderal Achmad Yani Cimahi, Ilmu \\ Keperawatan (S-1), Indonesia \\ Jl. Terusan Jend. Sudirman, Baros, Kec. Cimahi \\ Tengah, Kota Cimahi, Jawa Barat 40633 \\ Email Corespondent ratnaradina@gmail.com
}

\section{open 2 access}

Editor: ks

Received: 27/10/2021

Accepted: 21/12/2021

Published: 30/12/2021

Available Article:

10.33221/jiiki.v11i03.1372

Copyright: (C2021 This article has open access and is distributable under the terms of the Creative Commons Attribution License, which permits unrestricted use, distribution and reproduction in any medium, provided the name of the author and the original source are included. This work is licensed under a Creative Commons Attribution-Share Alike 4.0 International License

Conflict of interest statement:

There is no conflict of interest in this research.

Funding: Personal Funding

\begin{abstract}
Abstrak
Background: Adolescence is a period in which a child experiences a transition from childhood to adulthood both physically and psychologically. In 2018 the prevalence of smokers in the population aged $>10$ years in Indonesia, especially West Java, was ranked first at $32.0 \%$, while the smoking prevalence in the population aged 10-18 years was $9.1 \%$ in 2018, this number increased from 2013 which was only $7.2 \%$. Mental health is important in determining the quality of a nation. The phenomenon when the incidence of health problems in adolescents increases, the underlying cause comes from internal and external factors, this problem is still a threat if not treated immediately.

Objective: This study aims to determine the relationship between anxiety levels and smoking behavior in early adolescents.

Methods: The research design used is a correlation study with a cross sectional design. The number of samples was 55 male students in grades 7 and 8 in Nias Ciranjang junior high school which were selected through purposive sampling technique. Data collection filled out the Depression Anxiety Stress Scale 42 (DASS 42) questionnaire, $r_{\text {count }}>r_{\text {table }} 0,514$ and $r_{\text {alpha }}$ value $=0,952$. Data analysis was carried out univariate (frequency distribution) and bivariate with chi square test.

Result: The results showed that some respondents had moderate anxiety levels as much as $54.5 \%$, most respondents had bad smoking behavior as much as $54.5 \%$, and there was a relationship between anxiety levels and smoking behavior in early adolescents in Nias Ciranjang junior high school with $\mathrm{p}$ value $=0.001$.

Conclusion: It is hoped that nursing science and schools will continue to improve students' understanding of the dangers of smoking through counseling or other activities so that there are no more teenagers smoking.
\end{abstract}

Keywords: adolescents, smoking behavior, anxiety. 
The Relationship between Anxiety Levels and Smoking Behavior in Early Adolescents in Nias Ciranjang Junior High School

\section{Introduction}

Adolescence is part of human growth and development that will be experienced by every human being towards growth and development from the age of 13-17 years and the end of adolescence at the age of 17-18 years, this very short period of adolescence has the characteristics of an important period, the transition period, the period of change, the problematic age, the age that causes fear, the unrealistic period, the threshold of the future and the period of seeking self-identity. ${ }^{1,2}$ During adolescence, many biological, psychological, and social changes occur. But generally, the physical maturation process occurs faster than the psychological (psychosocial) maturation process. Humans are always seen as a unified whole of the elements of the body, soul, social, not only focused on the disease but on improving the quality of life, consisting of the welfare of the body, soul, and socio-economic productivity. Several types of mental disorders that often occur in adolescence, various stressors can arise, various negative conditions such as anxiety, depression, and even triggering the emergence of psychotic disorders can arise. Adolescent mental health is important in determining the quality of the nation. Adolescents who grow up in a conducive and supportive environment are human resources that can become invaluable national assets.

Deviant behavior in adolescence occurs because of the additional burden of tasks and thoughts, so it is undeniable that many teenagers experience increased anxiety due to a lack of individual coping in overcoming problems such as increasing assignments from school, the new environment they occupy, demands from parents to get grades. appropriate and other loads. So that many factors cause teenagers to do deviant behavior to seek other pleasures to make themselves feel comfortable, relax and forget the tasks that must be done, such as skipping classes with friends, playing games, fighting among students to seek attention, smoking, drinking alcohol and even taking drugs. ${ }^{2}$ The current phenomenon is the increasing incidence of mental health disorders in adolescents, the underlying cause comes from internal and external factors.

Smoking is one of the alternatives used by teenagers to relieve the anxiety they experience Soetjiningsih, 2012 Cigarettes contain nicotine, the effect of nicotine in cigarettes makes a person an addict or dependent on cigarettes, so cigarettes can be a gateway to try drugs because of the addictive effects of cigarettes. ${ }^{1}$ Adolescent who at first only tried smoking but eventually became addicted, then teenagers would start trying other things such as alcohol, drugs, and even other deviant behavior because smoking is an initial behavior or stepping stone behavior. ${ }^{4}$ Smoking habits in adolescents are one of the problems that interfere with adolescent health, the most dangerous negative impact of cigarettes, both on adolescents who smoke or who are exposed to cigarette smoke is the weakening of the nervous system which can interfere with concentration and memory due to the effects of nicotine in cigarettes. , this causes students to not be able to study well. ${ }^{1}$

Based on the results of the 2018 Basic Health Research, it was stated that the number of people over 15 years old in West Java was 10,849,182 people, and those who consumed tobacco tended to decrease slightly, data in 2010 showed $34.7 \%$, in 2013 showed $36.3 \%$ and in in 2018 was $33.8 \%$. But in 2018 the prevalence of smokers in the population aged > 10 years in Indonesia, especially West Java, was ranked first at $32.0 \%$, while the smoking prevalence in the population aged 10-18 years was $9.1 \%$ in 2018, this number increased from 2013 which was only 7.2\%. ${ }^{5}$ Based on the results of the data (Global Youth Tobacco Survey (GYTS), 2018) it turns out that the survey results in 2017 showed the number of smokers in Indonesia aged 15 years and over, men reaching 72\%. GYTS said 30.1\% of school children smoked. Although the proportion of female smokers is lower than male smokers, there has been a 5-fold increase from $1.7 \%$ in 2016 to $6.7 \%$ in 2017. Many factors cause teenagers to become smokers, including psychological factors because of the many burdens, demands, and problems that teenagers receive and are not resolved when teenagers are forming their identity, causing anxiety until they finally seek peace of mind and relax by smoking. ${ }^{1}$ Based on the results of Setyadin's research (2017) in his research, it was found that the higher the anxiety, the higher the smoking behavior. Vice versa, the lower the level of anxiety, the lower the smoking behavior. ${ }^{6}$

Perestroika (2012) in Eny Suyamti, et al (2018) states that anxiety is also called anxiety, anxiety is a state of feeling (mood) marked by physical symptoms such as physical tension and worries about 
The Relationship between Anxiety Levels and Smoking Behavior in Early Adolescents in Nias Ciranjang Junior High School

the future. Anxiety can be sourced from the inability of oneself to deal with a certain situation and a negative view of the environment and oneself. Anxiety is a psychological reaction that can be experienced by anyone anytime and anywhere. The level of anxiety experienced by each individual is influenced by the length of anxiety and how the individual copes with the anxiety he faces. ${ }^{7}$ Symptoms of anxiety that often arise are excessive anxiety, worry, restlessness, doubt, indecision, lack of selfconfidence, nervousness when appearing in public, insistent, anxious, often hysterical when emotional, irritable, often complain about this and that not easy to give in, blame others. ${ }^{8}$

The role of nurses as part of health workers has a very important task, responsibility, and role in efforts to stop smoking. One of the roles of nurses is as counselors and health educators (health education), namely providing health education, providing emotional and intellectual support to individuals, families, groups, and communities to instill healthy living behaviors so that behavior changes occur to achieve optimal health levels. ${ }^{9}$ Research conducted by Setyadin (2019) at the University of Muhammadiyah Surakarta regarding the relationship between anxiety and smoking behavior in college students found that from 30 male students, 28 experienced anxiety. The results of this study are that there is a very significant positive relationship between anxiety and smoking behavior in students. The percentage of anxiety about smoking behavior is $72.7 \%$ and the remaining $27.3 \%$ is influenced by other factors. ${ }^{6}$ Research conducted by Noni Hilda, et al (2017) at Sam Ratulangi University Manado about the relationship between stress levels and smoking behavior obtained significant results between stress levels and smoking behavior where the higher a person's stress level, the heavier smoking behavior with a percentage of $37.7 \% .^{10}$

Based on the results of a preliminary study conducted by the author, from the results of observations and interviews that the researchers conducted on February 21, 2020, on students of Nias Ciranjang junior high school which were carried out randomly, to adolescent smokers, 10 students were willing to be interviewed. From the results of interviews, students said they often felt annoyed so they were easy to say rude, excessive anxiety, difficulty concentrating, felt that schoolwork was a heavy burden, they said that they started smoking in 6th grade because they tried to try, were invited by friends, saw their parents, to calming to get a sense of comfort and relaxation when there are many school assignments, besides that they say that smoking can increase a sense of enthusiasm and valor. Students usually smoke during the hours before going to school, taking breaks, coming home from school, and when gathering with friends which are done secretly outside the school area without the teachers and parents knowing.

Based on the above phenomenon, the researcher wants to know how much smoking behavior a strong relationship to the aggravation of anxiety levels has as one of the factors causing mental health disorders in adolescents. The purpose of this study was to determine the relationship between anxiety levels and smoking behavior in early adolescents at Nias Ciranjang Junior High School.

\section{Method}

The research design used a correlation study with a cross-sectional design, namely research or study of the relationship between independent variables (anxiety levels) and related variables (smoking behavior) in a group of subjects (adolescents). The population in this study was male adolescent students aged 12-15 years at the Nias Ciranjang junior high school, Cianjur Regency, for the 2019/2020 school year for grades 7 and 8 as many as 118 students.

The sample in this study were male adolescents aged 12-15 years at Nias Ciranjang Junior High School. Sampling in this study is to use a non-probability sampling technique, namely purposive sampling. Inclusion criteria include male teenagers at SMP Nias Ciranjang who are still registered as active students. Adolescents with mild-to-severe anxiety levels according to the Depression Anxiety Stress Scale score 42 (DASS 42). Teen smoking. The exclusion criteria included deciding not to continue filling out or not filling out the complete questionnaire. Adolescents who are sick or have chronic diseases. Have discomfort at the time of research.

Data collection begins with an application for permission to the school. Data collection is done 
The Relationship between Anxiety Levels and Smoking Behavior in Early Adolescents in Nias Ciranjang Junior High School

online via a google form. Informed consent was obtained from the respondents. This research has been approved by the STIKes Ethics Committee General Achmad Yani Cimahi with No: 021/Kepk/VII/2020. The instrument of this research is to use a questionnaire. A questionnaire was used to measure anxiety with smoking behavior. Anxiety in this study was measured using a modified Depression Anxiety Stress Scale 42 (DASS 42) questionnaire from Lovibond (1995). DASS 42 is an instrument to determine the level of depression, anxiety, and stress, DASS 42 consists of 42 items. DASS 42 is a standardized test that has been accepted internationally, with an alpha coefficient of depression 0.947 , anxiety 0.897 , and stress 0.933 , and has a reliability value of 0.93 so that this anxiety level research instrument is reliable. ${ }^{11}$ The author only chooses a questionnaire that measures anxiety, namely several 14 questions contained in item numbers $2,4,7,9,15,19,20,23,25,28,30,36,40$, 41.

The smoking behavior questionnaire created by Martiani in 2016 was used in this study. The smoking behavior questionnaire uses a Likert scale with 20 statements with positive questions $(5,7,9,13,14,15,17,18,19$, and 20) and negative statements $(1,2,3,4,6,8,10,11,12$, and 16) which consists of three alternative answers, namely Never $=1$, Sometimes $=2$ and, often $=3$. The item is based on a negative statement, but if the statement is positive then the score is reversed to Never $=3$, Sometimes $=2$, and often $=1$. With the results of bad smoking behavior if mean 41.42 , smoking behavior is very bad if > mean 41.42. The smoking behavior instrument has been tested and used in a study conducted by Martiani (2016). 20 questions have a value of $r_{\text {count }}>r_{\text {table }} 0,514$ so they are declared valid. It was also found that the $r \_$alpha value on the smoking behavior questionnaire $=0.952$ so $>0.6$ (constant), then the questions on the smoking behavior questionnaire were reliable. ${ }^{12}$

The variables in this study were divided into two categories, namely: The independent variable in this study was the level of anxiety. The variable in this study is smoking behavior. Processing and data analysis using univariate and bivariate analysis with Chi-Square analysis. In this study, the data normality test, validity, and reliability test were also carried out.

Result

$\underline{\text { Table 1. Frequency Distribution of Anxiety Levels }}$

\begin{tabular}{ccc}
\hline Fear & Frequency $(\mathbf{F})$ & Percent $(\boldsymbol{\%})$ \\
\hline Light & 15 & 27,3 \\
Medium & 30 & 54,5 \\
Heavy & 10 & 18,2 \\
\hline Total & $\mathbf{5 5}$ & $\mathbf{1 0 0}$ \\
\hline
\end{tabular}

The results of the analysis in Table 1 above show that of the 55 respondents, most of them experienced moderate anxiety as many as 30 respondents $(54.5 \%)$.

Table 2. Frequency Distribution of Smoking Behavior

\begin{tabular}{ccc}
\hline Smoking Behavior & Frequency $(\mathbf{F})$ & Percent (\%) \\
\hline Bad & 30 & 54,5 \\
Very Bad & 25 & 45,5 \\
\hline Total & $\mathbf{5 5}$ & $\mathbf{1 0 0}$ \\
\hline
\end{tabular}

The results of the analysis in table 2 above show that of the 55 respondents, most of them have bad smoking behavior as many as 30 respondents $(54.5 \%)$. 
The Relationship between Anxiety Levels and Smoking Behavior in Early Adolescents in Nias Ciranjang Junior High School

Table 3. The Relationship between Anxiety Levels and Smoking Behavior in Early Adolescents in Nias Ciranjang Junior High School

\begin{tabular}{|c|c|c|c|c|c|c|c|}
\hline \multirow{3}{*}{ Fear } & \multicolumn{4}{|c|}{ Smoking Behavior } & \multicolumn{2}{|c|}{ Total } & \multirow[t]{2}{*}{ P-Value } \\
\hline & \multicolumn{2}{|c|}{ Bad } & \multicolumn{2}{|c|}{ Very Bad } & & & \\
\hline & $\mathbf{F}$ & $\%$ & $\mathbf{F}$ & $\%$ & $\mathbf{N}$ & $\%$ & \multirow{5}{*}{0,001} \\
\hline Light & 13 & 86,7 & 2 & 13,3 & 15 & 100 & \\
\hline Medium & 16 & 53,3 & 14 & 46,7 & 30 & 100 & \\
\hline Heavy & 1 & 10.0 & 9 & 90,0 & 10 & 100 & \\
\hline Total & 30 & 54,5 & 25 & 45,5 & 55 & 100 & \\
\hline
\end{tabular}

Based on Table 4.3, from 55 respondents it is known that of 15 respondents who have mild anxiety levels, almost all respondents have bad smoking behavior as many as 13 respondents $(86.7 \%)$, of 30 respondents who have moderate anxiety levels, almost some have bad smoking behavior. bad smoking as many as 16 respondents $(53.1 \%)$, and from 10 respondents who have a severe level of anxiety, almost all respondents have very bad smoking behavior as many as 10 respondents $(10.0 \%)$.

The results of statistical tests obtained p-value $=0,001<0,05$ then the hypothesis test is $H_{0}$ rejected, so it can be concluded that there is a relationship between anxiety levels and smoking behavior in early adolescents in Nias Ciranjang Junior High School.

\section{Discussion}

\section{Overview of Anxiety Levels in Early Adolescents at SMP Nias Ciranjang}

The results of the research from the independent variables can be concluded that in general, the anxiety level of early adolescents at SMP Nias Ciranjang is at a moderate level of anxiety. At a moderate level of anxiety, the individual begins to focus on things that are important and puts others aside. A person's attention becomes selective but can do something more directed through direction from others (Dr. Jenita, 2019). In this study, from 55 respondents, most of them had moderate levels of anxiety, 30 respondents $(54.5 \%)$. These factors can be caused by three sources, namely physical aspects such as dizziness, headache, sweaty hands, nausea, dry mouth, and nervousness. Emotional aspects, such as panic and fear. Cognitive aspects, such as attention and memory disorders, worry, and confusion (Shah, in Ghufron 2014). In this study, the cause of adolescents experiencing moderate anxiety was due to physical aspects, fatigue, fear for no apparent reason, panic, excessive anxiety about new tasks and roles faced by adolescents at school. ${ }^{13}$

Based on the results of respondents' answers from the results of the questionnaire statement, almost all respondents answered that they felt excessively anxious in a situation but could be relieved if the thing/situation ended, felt fear for no apparent reason, tired, easily panicked, afraid of being hampered by tasks that did not work. normal activities, fear, sweating (e.g., sweaty hands) without stimulation by weather or physical exercise, dry mouth, shaking, weakness in limbs, changes in heart activity and pulse rate without stimulation by physical exercise (eg sports), feeling disturbances in breathing (rapid breathing, difficulty breathing) and worry about situations when you feel panicked and embarrass yourself.

A large number of tasks and thoughts on adolescents causes many adolescents to experience increased anxiety due to a lack of individual coping in overcoming problems such as more assignments from school, the new environment they occupy, demands from parents to get appropriate grades, and other burdens. Respondents as teenagers have the desire to be able to overcome their problems but cannot do so because they do not dare to express their opinions to parents, teachers, school rules, and their friends. Stuart (2013) suggests that adolescents coping with anxiety is a process of overcoming anxiety by deceiving themselves. Individuals usually deal with anxiety using problem-focused coping mechanisms, cognitive-focused coping mechanisms, and emotion-focused coping mechanisms. 
The Relationship between Anxiety Levels and Smoking Behavior in Early Adolescents in Nias Ciranjang Junior High School

Coping can be identified through the manifestation response (signs of symptoms). ${ }^{14}$ The results of this study are in line with the research of Budi Arum (2011) which showed that most of the male adolescents in Colombo Senior High School, Sleman Regency experienced a moderate level of anxiety, namely $59.83 \%$.

\section{Overview of Smoking Behavior in Early Adolescents in Nias Ciranjang Junior High School}

The results of this study indicate that the smoking behavior of students is related to the level of anxiety experienced by the students themselves. In addition, psychiatric factors are closely related to adolescents with anxiety disorders who can use cigarettes to relieve the anxiety they experience, other factors that aggravate a teenager's smoking behavior are environmental factors that are closely related to the circumstances around adolescents in smoking behavior, namely the family environment, smoking parents, peers, the community, and cigarette advertisements. Respondents used in this study were early teens aged 12-15 years. Adolescence is an age that has a strong desire to try something new that is challenging because teenagers want to find their identity. It is further clarified with the theory (Komasari and Helmi, 2000 in Ramadhan, 2016) that youth search for identity by smoking. In general, teenagers who smoke are at the initiation stage and become a smoker because teenagers who smoke start from trial and error until they eventually become a smoker. ${ }^{15}$

Based on the results of the research above, from 55 respondents, most of them have bad smoking behavior as many as 30 respondents $(54.5 \%)$. Respondents in this study had bad smoking behavior. Although it has been widely proven that tobacco consumption hurts health status, respondents continue to smoke. In general, the factors that influence adolescent smoking are the influence of friends, personality factors, and the influence of advertising. In this study, the reason respondents smoked was that they tried it, were invited by friends, saw their parents, to calm them down, get a sense of comfort and relax when they had a lot of schoolwork, besides that they said that smoking can increase their sense of enthusiasm and valor. Based on respondents' answers from statements through questionnaires, from the aspect of smoking function, almost all respondents answered smoking to increase enthusiasm, smoking to get a sense of comfort and relaxation, to relieve feelings of anger, smoking when in discomfort, and sometimes smoking when not feeling well. body. From the aspect of smoking intensity, almost most of the respondents smoked more than 15 cigarettes or 1 pack in one day, most of the respondents if the cigarettes they smoked were about to run out, they prepared the next cigarette and smoked when they were with friends. In terms of the smoking area, almost a few respondents smoked in a smoking area, most of the respondents smoked when they were in the toilet, few smoked when they were in public transportation, and did not smoke when they were with their family. In the aspect of smoking time, most of the respondents smoked more when there was a problem, respondents felt they could not survive not smoking for one year, sometimes smoked when they were relaxed, and some would stop smoking if other people were disturbed by cigarette smoke.

According to Hurlock (2014), the self-identity that adolescents are looking for is in the form of clarity about who they are and what their role is in society. Adolescents are not satisfied if they are the same as most people, they want to show themselves as individuals, while at the same time they want to defend themselves against peer groups. If a teenager has a community of friends who smoke, likely, the teenager will also be affected by smoking. At first, maybe the teenager just wanted to try because of a friend's persuasion or as a form of solidarity, over time this behavior can become a habit because the nicotine in cigarettes has an addictive effect on the wearer. ${ }^{2,16}$ The results of this study are in line with Priyandio's (2013) research, that most respondents have bad smoking behavior (57.5\%).

\section{The Relationship between Anxiety Levels and Smoking Behavior in Early Adolescents at Niac Ciranjang Junior High School}

Based on the results of the study above, it was found that from 55 respondents it was known that of 15 respondents who had mild anxiety levels, most had bad smoking behavior as many as 13 
The Relationship between Anxiety Levels and Smoking Behavior in Early Adolescents in Nias Ciranjang Junior High School

respondents (86.7\%), of 30 respondents who had moderate levels of anxiety, almost most respondents had bad smoking behavior. bad smoking as many as 16 respondents (53.3\%), and of the 10 respondents who have a severe level of anxiety, most have very bad smoking behavior as many as 9 respondents $(90.0 \%)$. The results of statistical tests obtained p-value $=0.001<0.05$, then the hypothesis test is $\mathrm{H}_{0}$ rejected, so it can be concluded that there is a relationship between anxiety levels and smoking behavior in early adolescents in Nias Ciranjang Junior High School.

Based on the statistical results above, it is said that smoking behavior is bad, namely the high frequency and intensity of teenagers in smoking which is the background for teenagers such as teenagers using cigarettes to increase enthusiasm, get a sense of comfort, and relax when there are many tasks, they have to do to reduce the tension and anxiety that teenagers experience. When adolescents experience mild anxiety, adolescents will become more alert but can still motivate themselves to learn and generate growth and creativity. Meanwhile, when adolescents experience moderate anxiety, adolescents will become more selective but can still receive direction from others. In severe anxiety, behavior is more aimed at reducing the tension experienced by adolescents. Smoking is one form of a youth escaping from the problems that cause anxiety. The increasing number of tasks and thoughts causes adolescents to experience anxiety due to the lack of individual coping in dealing with problems such as more assignments from school. Causes teens to look for other pleasures to make themselves feel comfortable, relaxed, and forget the tasks that must be done.

Based on the above, adolescents need to know strategies in dealing with anxiety other than smoking or other negative actions. Abdul Hayat (2014), Strategies to deal with anxiety include breathing relaxation, this form of relaxation is called respiratory relaxation which can be done in situations that do not allow complicated relaxation. For example, annoyance has to complete a pile of tasks, so it is called the easiest and cheapest relaxation. This relaxation is seen as an easy and inexpensive way to turn anxiety into a passion for life and can control emotions and delay anger. ${ }^{17}$ The results of this study are in line with research conducted by Budi Arum (2011) which found that there is a positive relationship between stress levels and smoking behavior, which means that high-stress levels also have high smoking behavior. Another study by Setyadin (2019) found that there was a very significant positive relationship between anxiety and smoking behavior. ${ }^{6}$

Based on the results of research answers from respondents, it can be analyzed that respondents tend to experience fluctuating feelings such as being easily overly anxious in a situation but can be relieved when the thing/situation ends, fear for no apparent reason, fatigue, and easy to panic. While on smoking behavior, respondents tend to use cigarettes to increase enthusiasm and make them comfortable, and also relax when they get tense. Anxiety will never disappear from the daily life of individuals because it is a normal consequence of growth, change, new experiences, the discovery of identity, and the meaning of life. So that teenagers are always approached with school-related anxiety such as anxiety because it is difficult to concentrate and anxious feeling that schoolwork is a heavy burden. This study has a limited number of sampling needs to be reproduced and not limited to male adolescents, and an observation technique is needed to objectively assess the level of anxiety, reports from the school and parents reports to support the results of the respondents' self-reports.

\section{Conclusion}

Based on the research, data analysis, and discussion that has been carried out regarding the relationship between anxiety levels and smoking behavior in adolescents at SMP Nias Ciranjang to 55 respondents, it can be concluded that the results of the study are as follows: 1) The level of anxiety in adolescents is known to be mostly (54.5\%) is moderate, as many as 30 respondents. 2) Smoking behavior in adolescents is known to be almost half (54.5\%) is bad, as many as 30 respondents. 3) There is a relationship between the level of anxiety and smoking behavior in adolescents at SMP Nias Ciranjang with a p-value $=0.001$.

Based on the results of respondents' answers from the results of the questionnaire statement, almost all respondents answered that they felt excessively anxious in a situation but could be relieved 
The Relationship between Anxiety Levels and Smoking Behavior in Early Adolescents in Nias Ciranjang Junior High School

if the thing/situation ended, it can be seen from teenagers who have the desire to be able to overcome their problems but cannot do so because they do not dare to express their opinions. to parents, teachers, school rules, and their friends. This encourages most respondents to smoke more when there is a problem, respondents feel unable to survive not smoking for one year, sometimes smoke when they are relaxed, and some will stop smoking if other people are disturbed by cigarette smoke. So that it becomes a reason for teenagers to use cigarettes to increase enthusiasm, get a sense of comfort and relax when they have many tasks to do to reduce the tension and anxiety that teenagers experience. Teenagers need to be equipped with the knowledge of how to deal with anxiety in addition to smoking or other negative actions. For further researchers who are interested in researching the same topic, it is recommended to examine other factors such as the influence of parents who smoke and add female respondents, because there are already many women who smoke.

\section{Conflict of Interest Declaration}

There is no conflict of interest in this research

\section{Acknowledge}

Thank you to all participants in this study

\section{Funding}

Personal Funding

\section{Reference}

1. Soetjiningsih S. Tumbuh kembang remaja dan permasalahannya. 3rd ed. Vol. 320, Sagung Seto. Jakarta. Jakarta: Sagung Seto; 2012.

2. Hurlock EB. Psikologi Perkembangan Suatu Pendekatan Sepanjang Rentang Kehidupan. Jakarta: Erlangga; 2014.

3. Indarjo S. Kesehatan jiwa remaja. KEMAS J Kesehat Masy. 2009;5(1).

4. Mulyandari IT. Merokok, minum alkohol, dan hubungan seksual pada remaja survei demografi dan kesehatan Indonesia tahun 2012= Smoking, alcohol drinking, and premarital sex in adolescent Indonesia demographic and health survey 2012. 2014;

5. Laporan Hasil Riset Kesehatan Dasar (Riskesdas)| Badan Penelitian dan Pengembangan Kesehatan.

6. Setyadin AAN, Uyun Z. Hubungan Antara Kecemasan Dengan Perilaku Merokok Pada Mahasiswa. Universitas Muhammadiyah Surakarta; 2020.

7. Suyamti E, Hastuti W. Gambaran Tingkat Kecemasan Remaja Putri Kelas VII dan VIII Yang Mengalami Pubertas. Profesi (Profesional Islam Media Publ Penelit. 2018;16(1):78-83.

8. Annisa DF, Ifdil I. Konsep kecemasan (anxiety) pada lanjut usia (lansia). Konselor. 2016;5(2):93-9.

9. Fhirawati F, Sihombing RM, Hutapea AD, Supinganto A, Siburian CH, Noradina N, et al. Konsep Dasar Keperawatan. Yayasan Kita Menulis; 2020.

10. Bawuna NH, Rottie J, Onibala F. Hubungan antara tingkat stres dengan perilaku merokok pada mahasiswa Fakultas Teknik Universitas Sam Ratulangi. J Keperawatan. 2017;5(2).

11. Jamil J. Sebab Dan Akibat Stres, Depresi Dan Kecemasan Serta Penanggulangannya. Al Amin J Kaji Ilmu dan Budaya Islam. 2018;1(1):123-38.

12. Martiani. Hubungan Stress dengan Perilaku Merokok Pada Pasien Hipertensi di Poli Penyakit Dalam RSUD Cianjur. STIKES Jenderal Achmad Yani; 2016.

13. Donsu JDT. Psikologi keperawatan. 2019;

14. Moheby-Ahari C. Coping strategies and methods of managing psychological trauma during adolescence: an interpretative phenomenological perspective. 2014;

15. Ramadhan K. Hubungan Tingkat Stres Terhadap Frekuensi Merokok Mahasiswa Kedokteran Universitas Lampung. 2016;

16. Dwiyanto Y, Wahyudin MD, Isnaani RM, Ernawati D, Firmansyah D, Haryanti N, et al. The Effect of Smoking on Oxygen Saturation Level of Patients Covid-19. J Ilm Ilmu Keperawatan Indones. 2021;11(02):80-3.

17. Hayat A. Kecemasan dan metode pengendaliannya. Khazanah J Stud Islam Dan Hum. 2017;12(1). 